\title{
Cara Menyusun Company Description yang Menarik
}

\author{
Aryadewa Ramadhana Vavirya Putra \\ Program Studi Kewirausahaan \\ Universitas Bina Nusantara \\ aryadewa.putra@binus.ac.id
}

\section{A. Pengertian Company Description}

Company Description yang biasa dikenal sebagai biodata versi perusahaan merupakan gambaran umum suatu perusahaan. Company description merupakan bagian yang sangat penting dalam perusahaan. Company description menunjukkan kepada pembaca untuk mengetahui bagaimana menerjemahkan ide menjadi bisnis (Barringer, 2015).

\section{B. Langkah-Langkah Menyusun Company Description}

Merancang strategi usaha, menentukan tujuan dan keunggulan kompetitif merupakan langkah penting yang akan membedakan bisnis kalian dari yang lain (Siregar et al., 2020). Kalian dapat menuliskan ide-ide bisnis yang berbeda dan tidak biasa untuk bisa menarik perhatian pembaca di company description. Menyusun langkah company description dapat menggunakan metode $5 \mathrm{~W}+1 \mathrm{H}$, yang terdiri sebagai berikut.

\section{Who?}

Siapa kalian? Pastikan nama bisnis jelas di bagian deskripsi bisnis dari rencana bisnis kalian. Cantumkan nama pendiri dan nama pemilik lainnya karena pemberi pinjaman dan investor ingin mengetahui pengusaha di balik bisnis tersebut. Siapa target pelanggan kalian? Kepada siapa perusahaan menjual produk atau jasanya? Jika kalian tidak mengenal target pelanggan, ada kemungkinan tidak ada orang atau investor yang tertarik dengan ide bisnis kalian. Menentukan target pelanggan tidak akan membatasi bisnis kalian, tetapi dapat meningkatkan loyalitas pelanggan bisnis kalian kedepannya (Valdez, 2019).

\section{What?}

Apa produk atau layanan kalian?Jika pemberi pinjaman dan investor tidak dapat memahami apa yang kalian jual atau seberapa signifikan yang kalian jual, mereka mungkin akan meneruskan konsep kalian. Singkat, padat, dan jelas saat memberi tahu pemberi pinjaman dan investor tentang bisnis kalian. Apa tujuan kalian untuk memulai bisnis? Tetapkan tujuan jangka pendek dan jangka panjang 
yang realistis. Misalnya, jika kalian berencana menjual produk senilai Rp100.000.000,00 pada bulan ini, sebutkan tujuan dalam deskripsi bisnis.

\section{Where?}

Di mana lokasi bisnis kalian? Jika saat ini bisnis kalian telah berjalan, cantumkan alamatnya dan pastikan lokasi bisnis kalian strategis. Kalian dapat menentukan lokasi yang strategis dengan melihat kepadatan penduduk, pendapatan masyarakat sekitar, dan mengetahui tingkat persaingan di daerah tersebut (Sopian, 2020).

\section{When?}

Kapan kalian akan menerapkan rencana bisnis dan melihat hasilnya? Cantumkan juga kapan usaha akan dibuka, karena hal tersebut juga berpengaruh untuk jalannya usaha. Waktu terbaik untuk meluncurkan bisnis adalah setelah produk telah siap mulai dari fungsi dan manfaatnya (Dickmann, 2021). Kapan kalian berencana untuk mencapai tujuan perusahaan? Presentasikan alur atau perjalanan untuk mencapai tujuan utama baik jangka pendek maupun jangka panjang.

\section{Why?}

Mengapa calon pelanggan ingin membeli produk kalian? Jelaskan mengapa bisnis kalian berbeda dari pesaing. Orisinalitas bisnis kalian akan tergambarkan melalui penjelasan di tahap ini. Pemberi pinjaman dan investor ingin tahu mengapa konsumen ingin melakukan pembelian di bisnis kalian daripada di bisnis kompetitor. Pastikan juga kalian menyertakan misi bisnis. Pernyataan misi mendefinisikan mengapa kalian berada dalam bisnis tersebut dan apa tujuannya.

\section{How?}

Bagaimana kalian akan mencapai tujuan yang telah ditetapkan untuk bisnis? Apakah akan mempekerjakan karyawan atau akan menangani semua tanggung jawab sendiri? Presentasikan dengan tentang mengenai langkah apa yang akan diambil untuk mencapai tujuan yang telah kalian jelaskan. Bagaimana kalian membayangkan perusahaan di masa depan? Sertakan pernyataan visi bisnis dalam deskripsi perusahaan. Pernyataan visi adalah deskripsi internal yang menyatakan seperti apa bisnis kalian di masa depan.

\section{References}

Barringer, B. (2015). Preparing Effective Business Plans: An Entrepreneurial Approach, Global Edition (2nd Edition). Pearson Education Limited. https://online.vitalsource.com/reader/books/9781292059679/pageid/45

Dickmann, E. (2021, September 28). Determining the Right Timing for a Product Launch. Five Echelon. https://fiveechelon.com/determining-the-righttiming-for-a-product-launch/ 
Siregar, D., Purnomo, A., Mastuti, R., Napitupulu, D., Sadalia, I., Utami, D., Hendra, S., Hafni, S., Revida, E., \& Simarmata, J. (2020). Technopreneurship: Strategi dan Inovasi. Yayasan Kita Menulis. https://kitamenulis.id/2020/04/13/technopreneurship-strategi-dan-inovasi/ Sopian, A. (2020, May 15). 8 Tips Jitu Memilih Tempat Usaha Strategis. Jendela 360. https://jendela360.com/info/tempat-usaha-strategis/

Valdez, A. (2019, January 13). Advantages and Disadvantages of Undifferentiated Marketing. Bizfluent. https://bizfluent.com/info-8211055-advantagesdisadvantages-undifferentiated-marketing.html 